Kazuyuki Hamaguchi • Nguyen Duc Cong

Toshihiko Yanase $\cdot$ Shoichiro Ikuyama • Kiminobu Goto

Ryoichi Takayanagi $\cdot$ Hajime Nawata $\cdot$ Yoichiro Kusuda

Koji Fukagawa • Toshiie Sakata

\title{
Novel germline mutations of the MEN1 gene in Japanese patients with multiple endocrine neoplasia type 1
}

Received: July 30, 1998 / Accepted: August 31, 1998

\begin{abstract}
Multiple endocrine neoplasia type 1 (MEN1) is an autosomal dominant disorder characterized by tumors of the parathyroid glands, the pancreatic islet cells, and the anterior pituitary. Germline mutations of the MEN1 gene in three independent Japanese cases with MEN1 were analyzed. Case 1 has revealed a 2-bp (TA) insertion at nucleotide position 341 (341insTA) in exon 2, which shifts the reading frame such that the mutant protein has a completely different amino acid sequence from codon 78 to the premature stop codon at 119 . In case 2 , a nucleotide substitution, i.e., TAG in place of TGG, which encodes tryptophan at codon 198 was identified (nonsense mutation). These mutations were heterozygously present and have not been reported previously. Case 3 showed no mutations in the protein-coding exons and exon-intron junctions of the MEN1 gene by single-strand conformation polymorphism or direct sequencing of the polymerase chain reaction (PCR) fragments. We confirmed the finding that patients with MEN1 carry heterozygous germline mutations in the MEN1 gene, which is compatible with the idea that the $M E N 1$ gene is a tumor suppressor gene. The reason why mutations in the coding region of the MEN1 gene could not be detected by PCR-based analysis in some of the MEN1 patients, e.g. case 3 , needs to be clarified further.
\end{abstract}

Key words Multiple endocrine neoplasia type 1 (MEN1) · Menin - Germline mutation · Hereditary tumor syndrome . Tumor suppressor gene

K. Hamaguchi $(\bowtie) \cdot$ N.D. Cong $\cdot$ Y. Kusuda $\cdot$ K. Fukagawa

T. Sakata

Department of Internal Medicine I, Oita Medical University School of Medicine, 1-1 Idaigaoka, Hasama, Oita 879-5593, Japan

Tel. +81-97-586-5793; Fax +81-97-549-4480

e-mail: khamaguc@oita-med.ac.jp

T. Yanase $\cdot$ S. Ikuyama $\cdot$ K. Goto $\cdot$ R. Takayanagi $\cdot$ H. Nawata Third Department of Internal Medicine, Faculty of Medicine,

Kyushu University, Fukuoka, Japan

\section{Introduction}

Multiple endocrine neoplasia type 1 (MEN1, OMIM 131100) is an autosomal dominant disorder in which two or more of the following glands develop hyperplasia or adenoma: the parathyroid, the enteropancreas, and the pituitary (Wermer 1954). The prevalence of MEN1 in the Caucasian population has been reported to be between 1 per 100,000 to 1 per 10,000 of the population (Brandi et al. 1987). Although it is believed that the prevalence is rarer in Japan, i.e., about 150 cases (Yoshimoto and Saito 1991; Yoshimoto and Kimura 1996), a recent report indicates a similar incidence to the Caucasian population (Katai et al. 1997).

The MEN1 locus is on chromosome 11q13 (Larsson et al. 1988), and is a $300 \mathrm{~kb}$ or less gene-rich region flanked centromerically by PYGM and telomerically by D11S1783, as defined by combined meiotic and tumor deletion mapping studies. Recently, Chandrasekharappa et al. (1997) and Lemmens et al. (1997) have independently identified a gene responsible for MEN1, which encodes "menin" (Chandrasekharappa et al. 1997), a 610-amino-acid protein with no homologies to other proteins. MEN1 is proposed to be a tumor suppressor gene. Menin is implicated in transcriptional regulation, DNA replication, or cell cycle control, as it has recently been found in the nucleus (Guru et al. 1998).

Germline mutations in familial MEN1 kindreds and sporadic MEN1 cases have been identified recently among affected individuals in both Caucasian (Agarwal et al. 1997; Chandrasekharappa et al. 1997; Lemmens et al. 1997; Mayr et al. 1997; Bassett et al. 1998; Giraud et al. 1998; Teh et al. 1998) and Japanese populations (Aoki et al. 1997; Shimizu et al. 1997; Tanaka et al. 1998). Several identical mutations occurred in two or more unrelated kindreds. Furthermore, cases in which no mutation could be identified in the exons of the MEN1 gene were also reported. We analyzed the MEN1 gene in three independent Japanese cases in order to clarify further the molecular abnormality in MEN1. 
Table 1 Oligonucleotide primers used for polymerase chain reaction amplification and sequencing

\begin{tabular}{lllll}
\hline Forward primer & Position & Reverse primer & Position & fragment size (bp) \\
\hline 2F1: CGGGTGGAACCTTAGCGGAC & $2184-2203$ & 2R1: AAAGTAGGTGAGGCCGCCAG & $2502-2521$ & 338 \\
2F2: ACGTTCCCGAGCTCACCTTC & $2457-2476$ & 2R2: TGGATAAGATTCCCACCTACTG & $2742-2763$ & 307 \\
3F: AGAGGACCCTCTTTCATTAC & $4262-4281$ & 3R: ACAGTATGAAGGGGACAAG & $4577-4545$ & 284 \\
4F: TGTCATTCCCTGAAGCAGGC & $4650-4669$ & 4R: AAGTCAAGTCTGGCCTAGC & $4875-4893$ & 244 \\
5F: TTCCGTGGCTCATAACTCTC & $5142-5161$ & 6R: TCAGCCACTGTTAGGGTCTC & $5415-5434$ & 293 \\
7F: TGAGGATCCTCTGCCTCAC & $5996-6014$ & 7R: AGGGTGGTTGGAAACTGATG & $6209-6228$ & 233 \\
8F: ATGGTGAGACCCCTTCAGAC & $6576-6595$ & 8R: ATCCCTAATCCCGTACATGC & $6834-6853$ & 278 \\
9F: AAGGGGTGAGTAAGAGACTG & $7147-7166$ & 9R: AAAAGTCTGACAAGCCCGTG & $7411-7430$ & 284 \\
10F1: TGCTCTCACCTTGCTCTCC & $7547-7565$ & 10R1: CGTGCTGCCACCTTCAGG & $7812-7829$ & 283 \\
10F2: TGTCGCTGGCACAGCCCG & $7790-7807$ & 10R2: AGCCTGGGTCCCCACAAG & $8082-8099$ & 310 \\
\hline
\end{tabular}

Primers were made based on the nucleotide sequence of the human menin gene published by Chandrasekharappa et al. (1997) (GenBank accession number: U93237)

\section{Materials and methods}

\section{Case reports}

The first case is a 43-year-old Japanese male patient, whose father was diagnosed as having MEN1 (islet cell carcinoma and parathyroid tumor). At the age of 36 years, the patient was diagnosed as having prolactinoma of the pituitary gland, hyperparathyroidism, and pancreatic tumor. The parathyroid tumors were removed. Bromocriptin therapy was initiated for the treatment of prolactinoma. Five years later (at the age of 41 years), his pancreatic tumor was diagnosed as malignant insulinoma with liver metastasis. Subsequently, the insulinoma was treated with octreotide, and the metastatic lesion was treated with Smancs (zinostatin stimalamer, Yamanouchi Pharmacentical Co., Ltd, Tokyo, Japan). He has been followed up at an outpatient clinic in the Kyushu University Hospital.

The second case is a 62-year-old Japanese female patient, whose family history was negative. At the age of 53 years, pancreaticoduodenectomy was carried out for the treatment of malignant islet cell tumor. When she reached 60 years of age, preclinical Cushing's syndrome with left adrenal tumor, left parathyroid tumor, and nonfunctioning pituitary microadenoma were found. Tumors of the parathyroid and adrenal glands were removed. She has also been followed up at the outpatient clinic in the Kyushu University Hospital.

The third case is a 70-year-old Japanese male patient, whose brother had Zollinger-Ellison's syndrome and hypercalcemia, and who had a nephew diagnosed as having MEN1 (parathyroid tumor and insulinoma). His parents were deceased, and there is no information on whether they had MEN1. At the age of 66 years, surgical polypectomy was carried out for the duodenal carcinoid tumor. At the same time, tumors of the parathyroid glands, adenomatous goiter, and non-functioning pituitary microadenoma were found. The parathyroid tumors were subsequently resected, and partial thyroidectomy was carried out. He has been followed up at an outpatient clinic in the Oita Medical University Hospital.
Molecular analysis of the MEN1 gene

Written informed consent was obtained from all patients. Genomic DNA was extracted from blood leukocytes according to the method described previously (Kimura and Sasazuki 1992). To obtain segments for determination of the nucleotide sequence, the coding region of the MEN1 gene was amplified by polymerase chain reaction (PCR) using $1 \mu \mathrm{g}$ genomic DNA. Ten pairs of sense/antisense primers (Table 1) were used to amplify the fragments encompassing the protein-coding region of exons 2 to 10 . Using Taq DNA polymerase (Takara Shuzo, Tokyo, Japan) and the DNA Thermal Cycler (Iwaki Glass, Funabashi, Japan), PCR was performed as follows: initial incubation at $94^{\circ} \mathrm{C}$ for $3 \mathrm{~min} ; 1 \mathrm{~min}$ at $94^{\circ} \mathrm{C}, 1 \mathrm{~min}$ at $58^{\circ} \mathrm{C}, 1 \mathrm{~min}$ at $72^{\circ} \mathrm{C}$ for 30 cycles; and final extension at $72^{\circ} \mathrm{C}$ for $10 \mathrm{~min}$. Five percent dimethyl sulfoxide was included in the reaction mixture for the amplification of exons 7 and 10. The PCRamplified DNA fragments were analyzed by the singlestrand conformation polymorphism (SSCP) method as described elsewhere (Hoshino et al. 1992). PCR products which showed abnormal banding by SSCP were subcloned into the pCR II vector with the TA cloning kit (Invirogen, Carlsbad, CA, USA) and sequenced by the dideoxynucleotide method using the ABI Prism Dye Terminator Cycle Sequencing Core Kit (Perkin Elmer, Foster City, CA, USA). To distinguish mutations occurring in the original genomic sequence from random misincorporated nucleotides introduced by Taq DNA polymerase during PCR, PCR sequences from more than four clones were examined. The mutations found by the above method were further confirmed by direct sequencing of the PCR fragment.

\section{Results}

The SSCP analysis of the 307-bp PCR fragment amplified by primers $2 \mathrm{~F} 2$ and $2 \mathrm{R} 2$ from case 1 showed an abnormal band (Fig. 1a). Sequence analysis of this fragment subcloned into plasmids revealed a 2-bp (TA) insertion at nucleotide position 341 in exon 2 (codons 77-78) (Fig. 1b), 
Fig. 1a, b Analyses of the MEN1 gene, exon 2 from case 1 . a SSCP analysis. An abnormal band is indicated by an arrow. $C$ denotes the control individual. $P$ denotes case 1 . b Sequence analysis. A 2bp (TA) insertion at nucleotide 341 (codon 77-78) and the frame shift results in a completely different amino acid sequence from codon 78

\section{exon 2}

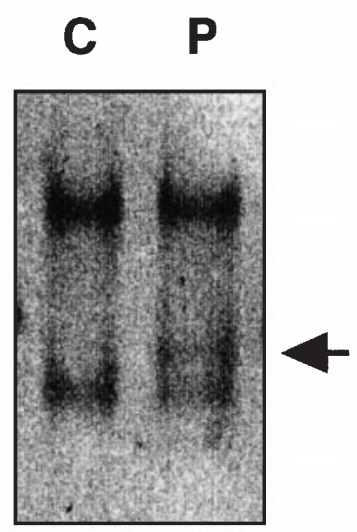

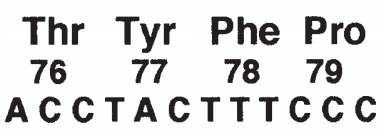
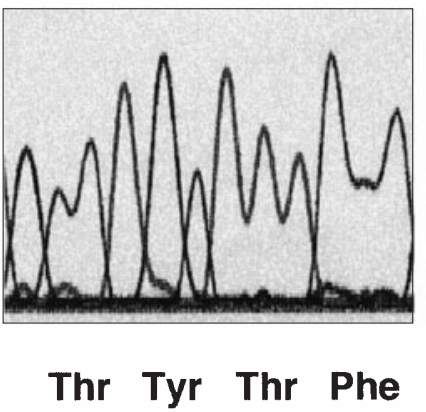

$\begin{array}{llll}76 & 77 & 78 & 79\end{array}$
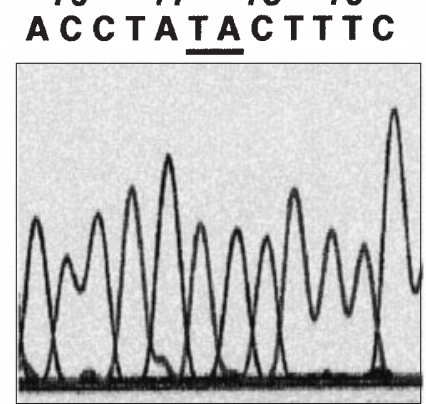

which shifts the reading frame such that the mutant protein could be expected to have a completely different amino acid sequence from codon 78 to the premature stop codon at 119. The SSCP analysis of the 284-bp PCR fragment amplified by primers $3 \mathrm{~F}$ and $3 \mathrm{R}$ from case 2 showed an abnormal band (Fig. 2a). Sequence analysis of this fragment subcloned into plasmids revealed a nucleotide substitution, i.e., TAG in place of TGG, which encodes tryptophan at codon 198 (nonsense mutation) (data not shown). The direct sequence of the PCR fragments also revealed that the mutation was heterozygously present in both case 1 (data not shown) and case 2 (Fig. 2b). Since the mutation found in case 2 generates a $B f a I$ restriction site, $B f a I$ digestion of the 284-bp PCR product amplified by primers 3F and 3R was carried out. This resulted in the appearance of two fragments, of $181 \mathrm{bp}$ and $103 \mathrm{bp}$, in addition to the original 284bp fragment, whereas the PCR product from a normal individual retained the same 284-bp fragment (data not shown). These results clearly indicate that the mutation is heterozygously present in the MEN1 gene of case 2 .

In contrast to cases 1 and 2, results of analysis of case 3 showed neither abnormal banding by SSCP analysis nor mutation in the protein-coding region and the exon-intron junction of the MEN1 gene by direct sequencing analysis.

\section{Discussion}

We have found two germline mutations, including an insertional and a nonsense mutation, in MEN1 patients, and these have not been described previously in Caucasian or Japanese patients. The mutation W198X has been reported in a Caucasian patient; however, the base change is different from our second case, i.e., TGA and TAG in a Caucasian patient (Chandrasekharappa et al. 1997) and in our case 2, respectively. These two novel mutations are likely to result in truncated and inactive menin proteins. Thus, we have confirmed the finding that patients with MEN1 carry heterozygous germline mutations in the MEN1 gene, which is consistent with the hypothesis that the $M E N 1$ gene is a tumor suppressor gene.

Since the discovery of the MEN1 gene, over 90 different germline mutations have been reported; 12 of them were found in Japanese MEN1 patients. Among these mutations, Bassett et al. (1998) reported hot spots for small deletions and insertions in exons 2, 3, and 10 . The mutations identified in the present study are also located at exons 2 and 3, where misalignment of the dinucleotide repeat during replication could easily be expected from the nucleotide sequence of this region (Krawczak and Cooper 1991). Irrespective of these mutational hot spots, the mutation sites are fundamentally distributed over the entire exon. Hence, screening has to be carried out throughout the coding region and exon/intron boundaries.

Direct genetic screening, but not indirect screening by haplotype analysis, may enable accurate diagnosis of MEN1. Thus, it is now feasible to establish genotypephenotype correlations in MEN1. However, the cases reported by Basset et al. (1998) indicate that correlations cannot be established either between families or within families. These observations should be built on further by describing patients' phenotypes more precisely.

It is noteworthy that there have been reports of some cases without any mutations in the coding region of the MEN1 gene. We could not find any mutation in the coding 
Fig. 2a,b Analyses of the MEN1 gene, exon 3 from case 2. a SSCP analysis. An abnormal band is indicated by an arrow. $C$ denotes the control individual. $P$ denotes case 2. b Direct sequence analysis. TGG and TAG (nonsense mutation) are heterozygously present at codon 198

\section{exon 3}

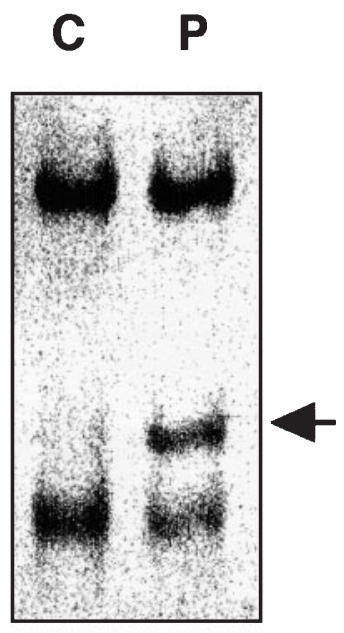

$\mathbf{a}$

region of MEN1 in one patient (case 3) even by direct sequencing. This may stem from a mutation in the untranslated region, an intron or the promoter region of the gene, or a large germline deletion which resulted in amplification of only the normal copy of MEN1 by PCR. Indeed, a large germline deletion of the MEN1 gene is reported in a Japanese kindred (Kishi et al. 1998). Our case 3 showed typical MEN1 phenotypes and the inheritance of the disease was verified at least in two generations (his brother and a nephew), although the heterogeneity of enteropancreatic tumors within the family exists (carcinoid tumor, gastrinoma, and insulinoma). Therefore, there is little doubt that case 3 has familial MEN1; however, it does not necessarily mean that the mutation should exist in the MEN1 gene. Since genetic heterogeneity is reported in a MEN1 kindred by $\mathrm{LOH}$ analysis (Stock et al. 1997), it is possible that gene(s) located other than on chromosome 11q13 might be responsible for MEN1-like syndromes. Moreover, it has recently been reported that a tumor suppressor gene other than MEN1 may exist on chromosome $11 \mathrm{q} 13$ (Chakrabarti et al. 1998).

Acknowledgments The authors thank Professor Tuan V. Nguyen, Wright State University School of Medicine, USA, for review of the manuscript.

\section{References}

Agarwal SK, Kester MB, Debelenko LV, Heppner C, Emmert-Buck MR, Skarulis MC, Doppman JL, Kim YS, Lubensky IA, Zhuang Z,
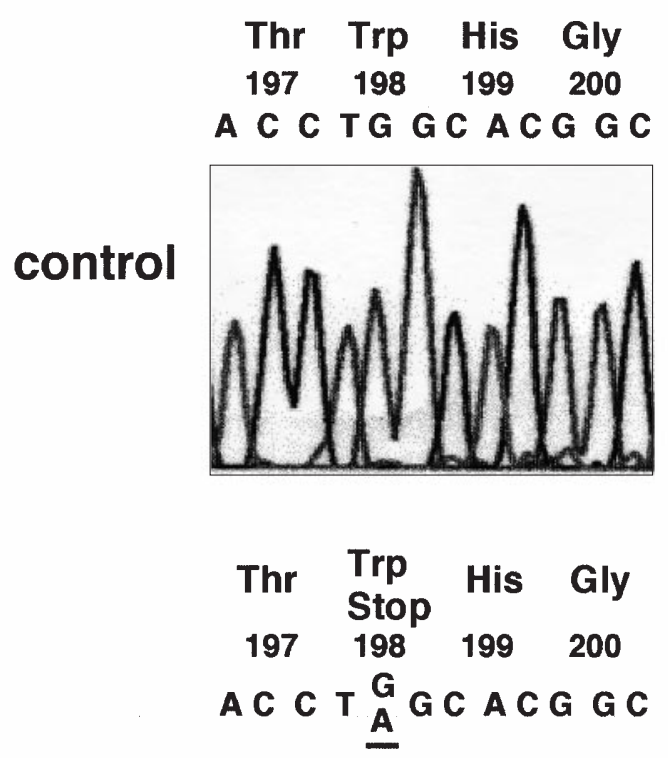

patient

b

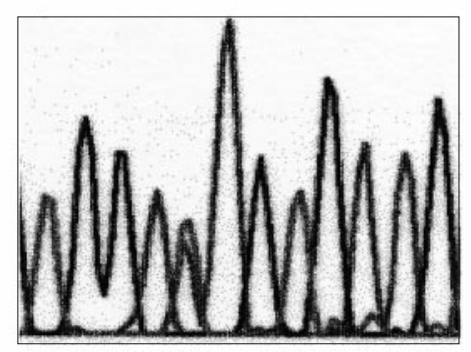

Green JS, Guru SC, Manickam P, Olufemi SE, Liotta LA, Chandrasekharappa SC, Collins FS, Spiegel AM, Burns AL, Marx SJ (1997) Germline mutations of the MEN1 gene in familial multiple endocrine neoplasia type 1 and related states. Hum Mol Genet 6: $1169-1175$

Aoki A, Tsukada T, Yasuda H, Kayashima S, Nagase T, Ito T, Suzuki T, Matsukuma S, Kuwabara N, Yoshimoto K, Yamaguchi K (1997) Multiple endocrine neoplasia type 1 presented with manicdepressive disorder: a case report with an identified MEN1 gene mutation. Jpn J Clin Oncol 27: 419-422

Bassett JH, Forbes SA, Pannett AA, Lloyd SE, Christie PT, Wooding C, Harding B, Besser GM, Edwards CR, Monson JP, Sampson J, Wass JA, Wheeler MH, Thakker RV (1998) Characterization of mutations in patients with multiple endocrine neoplasia type 1 . Am J Hum Genet 62: 232-244

Brandi ML, Marx SJ, Auerbach GD, Fitzpatrick LA (1987) Familial multiple endocrine neoplasia type I: a new look at pathophysiology. Endocr Rev 8:391-405

Chakrabarti R, Srivatsan ES, Wood TF, Eubanks PJ, Ebrahimi SA, Gatti RA, Passaro E Jr, Sawicki MP (1998) Deletion mapping of endocrine tumors localizes a second tumor suppressor gene on chromosome band 11q13. Genes Chromosomes Cancer 22: 130-137

Chandrasekharappa SC, Guru SC, Manickam P, Olufemi SE, Collins FS, Emmert-Buck MR, Debelenko LV, Zhuang Z, Lubensky IA, Liotta LA, Crabtree JS, Wang Y, Roe BA, Weisemann J, Boguski MS, Agarwal SK, Kester MB, Kim YS, Heppner C, Dong Q, Spiegel AM, Burns AL, Marx SJ (1997) Positional cloning of the gene for multiple endocrine neoplasia-type 1. Science 276: 404-406

Giraud S, Zhang CX, Serova-Sinilnikova O, Wautot V, Salandre J, Buisson N, Waterlot C, Bauters C, Porchet N, Aubert JP, Emy P, Cadiot G, Delemer B, Chabre O, Niccoli P, Leprat F, Duron F, Emperauger B, Cougard P, Goudet P, Sarfati E, Riou JP, Guichard S, Rodier M, Meyrier A, Caron P, Vantyghem MC, Assayag M, Peix JL, Pugeat M, Rohmer V, Vallotton M, Lenoir G, Gaudray P, Proye C, Conte-Devolx B, Chanson P, Shugart YY, Goldgar D, Murat A, Calender A (1998) Germ-line mutation analysis in patients with multiple endocrine neoplasia type 1 and related disorders. Am J Hum Genet 63: 455-467 
Guru SC, Goldsmith PK, Burns AL, Marx SJ, Spiegel AM, Collins FS, Chandrasekharappa SC (1998) Menin, the product of the MEN1 gene, is a nuclear protein. Proc Natl Acad Sci USA 95:1630 1634

Hoshino S, Kimura A, Fukuda Y, Dohi K, Sasazuki T (1992) Polymerase chain reaction-single strand conformation polymorphism analysis of polymorphisms in DPA1 and DPB1 genes: a simple, economical and rapid method for histocompatibility testing. Hum Immunol 33: 98-107

Katai M, Sakurai A, Itakura Y, Ikeo Y, Nakajima K, Hara M, Iijima S, Kaneko T, Kobayashi M, Ichikawa K, Aizawa T, Hashizume K (1997) Multiple endocrine neoplasia type 1 is not rare in Japan. Endocrinol J 44: 841-845

Kimura A, Sasazuki T (1992) Eleventh international histocompatibility workshop reference protocol for the HLA DNA-typing technique In: Tsuji K, Aizawa M, Sasazuki T (eds) HLA 1991. Oxford University Press, Oxford, vol 1, pp 397-419

Kishi M, Tsukada T, Shimizu S, Futami H, Ito Y, Kanbe M, Obara T, Yamaguchi K (1998) A large germline deletion of the MEN1 gene in a family with multiple endocrine neoplasia type 1 . Jpn J Cancer Res 89: $1-5$

Krawczak M, Cooper DN (1991) Gene deletions causing human genetic disease: mechanisms of mutagenesis and the role of the local DNA sequence environment. Hum Genet 86: 425-441

Larsson C, Skogseid B, Oberg K, Nakamura Y, Nordenskjold M (1988) Multiple endocrine neoplasia type 1 gene maps to chromosome 11 and is lost in insulinoma. Nature 332: 85-87

Lemmens I, Van de Ven WJM, Kas K, Zhang CX, Giraud S, Wautot V, Buisson N, De Witte K, Salandre J, Lenoir G, Pugeat M, Calender A, Parente F, Quincey D, Gaudray P, De Wit MJ, Lips CJ, Hoppener JW, Khodaei S, Grant AL, Weber G, Kytola S, Teh BT, Farnebo F, Phelan C, Hayward N, Larsson C, Pannett AAJ, Forbes SA, Bassett JHD, Thakker RV (1997) Identification of the multiple endocrine neoplasia type 1 (MEN1) gene. Hum Mol Genet 6: 11771183

Mayr B, Apenberg S, Rothamel T, von zur Muhlen A, Brabant G
(1997) Menin mutations in patients with multiple endocrine neoplasia type 1. Eur J Endocrinol 137: 684-687

Shimizu S, Tsukada T, Futami H, Ui K, Kameya T, Kawanaka M, Uchiyama S, Aoki A, Yasuda H, Kawano S, Ito Y, Kanbe M, Obara T, Yamaguchi K (1997) Germline mutations of the MEN1 gene in Japanese kindred with multiple endocrine neoplasia type 1. Jap J Cancer Res 88: 1029-1032

Stock JL, Warth MR, Teh BT, Coderre JA, Overdorf JH, Baumann G, Hintz RL, Hartman ML, Seizinger BR, Larsson C, Aronin N (1997) A kindred with a variant of multiple endocrine neoplasiatype 1 demonstrating frequent expression of pituitary tumors but not linked to the multiple endocrine neoplasia type 1 locus at chromosome region 11q13. J Clin Endocrinol Metab 82: 486-492

Tanaka C, Yoshimoto K, Yamada S, Nishioka H, Ii S, Moritani M, Yamaoka T, Itakura M (1998) Absence of germ-line mutations of the multiple endocrine neoplasia type 1 (MEN1) gene in familial pituitary adenoma in contrast to MEN1 in Japanese. J Clin Endocrinol Metab 83: 960-965

Teh BT, Kytola S, Farnebo F, Bergman L, Wong FK, Weber G, Hayward N, Larsson C, Skogseid B, Beckers A, Phelan C, Edwards M, Epstein M, Alford F, Hurley D, Grimmond S, Silins G, Walters M, Stewart C, Cardinal J, Khodaei S, Parente F, Tranebjaerg L, Jorde R, Menon J, Khir A, Tan TT, Chan SP, Zaini A, Khalid BAK, Sandelin K, Thompson N, Brandi ML, Warth M, Stock J, Leisti J, Cameron D, Shepherd JJ, Oberg K, Nordenskjold M, Salmela P (1998) Mutation analysis of the MEN1 gene in multiple endocrine neoplasia type 1 , familial acromegaly and familial isolated hyperparathyroidism. J Clin Endocrinol Metab 83: 2621-2626

Wermer P (1954) Genetic aspects of adenomatosis of endocrine glands. Am J Med 16: 363-367

Yoshimoto K, Kimura T (1996) Clinical features and genetic abnormalities in multiple endocrine neoplasia type 1. Folia Endocrinol Jpn 72: 137 (abstract) (in Japanese)

Yoshimoto K, Saito S (1991) Clinical characteristics in multiple endocrine neoplasia type 1 in Japan: a review of 106 patients. Folia Endocrinol Jpn 67: 764-774 (in Japanese) 